\title{
Party-Army Politics and the Origins OF THE CHINESE 2013 ADIZ
}

\author{
Matthew Kim Sullivan ${ }^{1}$
}

\section{INTRODUCTION}

The year of 2013 was an eventful year for Chinese foreign policy. In the fall of 2013, China announced its New Silk Road Economic Belt and its New Maritime Silk Road projects. Xi Jinping's speeches that year indicated that Xi Jinping envisioned that China would take a positive leading role in Asia-Pacific community. ${ }^{2}$ Ironically, in the midst of its diplomatic proclamations, China also announced the inception of an Air Defense Identification Zone that encompassed a swath of territory over the East China Sea including the disputed Senkaku (or Diaoyu) Islands. In short, this ADIZ requires foreign aircraft entering the designated area to notify Chinese authorities of their approach. ${ }^{3}$ Some experts have suggested that the Chinese created the 2013 ADIZ to assert a new political order in the East China Sea. ${ }^{4}$ However, there are many inconsistencies in the formation and execution of the ADIZ that make this assertion improbable. For example, a 2014 U.S. China Commission report stated:

An ADIZ allows China greater flexibility in asserting sovereignty over its ECS claims in a manner that does not controvert international

\footnotetext{
1 Matt Sullivan is Master's candidate at the Masters in Asian Studies Program at Georgetown School of Foreign Service. He has previously interned at the Center for Applied Strategic Learning at National Defense University and the Korea Economic Institute of America, and is currently at Armitage International L.C. Matt was adopted from Suwon, South Korea and grew up in Decorah, Iowa.

2 Jinping Xi, The Governance of China (Beijing, China: Foreign Languages Press, 2014). 315329, 360-367, 378-396.

3 "Statement by the Government of the People's Republic of China on Establishing the East China Sea Air Defense Identification Zone,” Xinhua News Agency, November 23, 2013, http://news.xinhuanet.com/english/china/2013-11/23/c_132911635.htm.

${ }^{4}$ Michael J. Green, "Safeguarding the Seas: How to Defend Against China’s New Air Defense Zone,” Foreign Affairs, December 2, 2013, https://www.foreignaffairs.com/articles/ china/2013-12-02/safeguarding-seas.
} 
conventions. The ADIZ is an expansion of China's attempt to exert legal and administrative control over the Senkaku Islands. Having issued a number of measures to assert de jure governance over disputed maritime regions, China now has laid an additional legal foundation intended to justify control of contested airspace. ${ }^{5}$

Yet, since there is no internationally legitimate basis for the installation of an ADIZ, nor are states legally required to comply with ADIZ protocol, it seems unlikely that the ADIZ substantially increased China's de jure power over the sea zone. ${ }^{6}$ In addition, while Chinese military presence in the East China Sea has increased since the establishment of the ADIZ, there is little evidence that indicates this military buildup is a direct result of the installation of the ADIZ. ${ }^{7}$ Furthermore, it appears that Chinese planners established the ADIZ despite its international unpopularity and its apparent lack of resolve to enforce its claims. ${ }^{8}$ China's ADIZ was denounced by many countries including the United States, Japan, South Korea, and Japan. ${ }^{9}$ International criticisms of the ADIZ include:

1. The ADIZ could be seen as a move to aggressively revise the regional order in the East China Sea. ${ }^{10}$

2. China failed to consult with other governments prior to establishing the zone. ${ }^{11}$

5 Kimberly Hsu, "Air Defense Identification Zone Intended to Provide China Greater Flexibility to Enforce East China Sea Claims" (U.S.-China Economic and Security Review Commission, January 14, 2014), https://www.uscc.gov/sites/default/files/Research/China\%20ADIZ\%20 Staff\%20Report.pdf.

6 David A. Welch, "What's an ADIZ?: Why the United States, Japan, and China Get It Wrong," Foreign Affairs, December 9, 2013, https://www.foreignaffairs.com/articles/east-asia/2013-12-09/ whats-adiz.

7 Michael Pilger, "ADIZ Update: Enforcement in the East China Sea, Prospects for the South China Sea, and Implications for the United States," Staff Research Report (Washington, DC:

U.S.-China Economic and Security Review Commission, March 2, 2016), 6.

8 Pilger, "ADIZ Update: Enforcement in the East China Sea, Prospects for the South China Sea, and Implications for the United States," 4.

9 Michael D. Swaine, "Chinese Views and Commentary on the East China Sea Air Defense Identification Zone (ECS ADIZ),” China Leadership Monitor, no. 40 (February 3, 2014), ${ }^{10}$ Michael J. Green, "Safeguarding the Seas: How to Defend Against China's New Air Defense Zone," Foreign Affairs, December 2, 2013, https://www.foreignaffairs.com/articles/ china/2013-12-02/safeguarding-seas.

11 Swaine, "Chinese Views and Commentary on the East China Sea Air Defense Identification 
3. China is attempting to assert control over the controversial Diaoyu/Senkaku Islands.

4. The 2013 ADIZ provocatively overlaps ADIZs already established by other states. ${ }^{12}$

In fact, several states have flown military aircraft over the zone in protest against the China's move. ${ }^{13}$ What makes this move even more peculiar is that it is inconsistent with other diplomatic and soft power goals the CCP was promoting in foreign affairs. During 2012-2014, some of these included the Belt and Road project, ${ }^{14}$ the Chinese Communist Party's (CCP) 'commitment to peaceful development' with other Asian states, ${ }^{15}$ and its desire to promote economic cooperation. ${ }^{16}$ In truth, the ADIZ does very little to augment Chinese de facto or de jure control over Northeast Asia. This leads us to wonder why the Chinese decided to establish the 2013 ADIZ, despite the fact that it had little strategic or intrinsic value and was inconsistent with other diplomatic agendas. Experts have proposed several possible explanations, which are explained belo

\section{Explanation I: Chinese Leaders Were Under Increased Nationalistic Pressure}

Some scholars have suggested that competing nationalism in East Asia has pressured the Chinese foreign policy and military establishment towards increasingly provocative rhetoric and actions, such as the ADIZ. ${ }^{17}$ China's colonial legacies and historic resentments inform and reinforce contemporary insecurities of national sovereignty and security; and many of China's territorial

Zone (ECS ADIZ)," 11.

${ }^{12} \mathrm{Hsu}$, "Air Defense Identification Zone Intended to Provide China Greater Flexibility to Enforce East China Sea Claims," 2.

${ }_{13}$ Swaine, "Chinese Views and Commentary on the East China Sea Air Defense Identification Zone (ECS ADIZ)." 12.

${ }_{14}$ Jinping Xi, "Work Together to Build the Silk Road Economic Belt: September 8, 2013," in The Governance of China (Beijing, China: Foreign Languages Press, 2014), 315-19.

${ }_{15}$ Jinping Xi, "China’s Commitment to Peaceful Development: March 28, 2014," in The Governance of China (Beijing, China: Foreign Languages Press, 2014), 290-289.

${ }^{16}$ Jinping Xi, "Work Together for a Better Asia Pacific: October 7, 2013," in The Governance of China (Beijing, China: Foreign Languages Press, 2014), 378-88.

${ }_{17}$ Michael J. Green, "Safeguarding the Seas: How to Defend Against China's New Air Defense Zone," Foreign Affairs, December 2, 2013, https://www.foreignaffairs.com/articles/ china/2013-12-02/safeguarding-seas. 
disputes, particularly with Japan, are fueled by this nationalism. ${ }^{18}$ These scholars argue that domestic nationalism played the defining role in the creation of the ADIZ; however, nationalism does not adequately explain this specific course of action, nor does it explain the PLA's inflated role in the establishment of the ADIZ.

\section{Explanation II: China Made a Miscalculation in Either its Decision or Implementation}

Other analysts suggest that the ADIZ was, in essence, a "mistake." In an article in the Diplomat, Zheng Wang speculates that faulty communication within the CCP foreign policy and defense apparatuses could have led to rash decision-making from senior policymakers resulting in the ADIZ. ${ }^{19}$ This belief is rooted in the difficulty and sluggishness that Chinese policymakers experience coordinating their foreign policy and military bureaucracies owing to the lack of a strong unifying national security apparatus. ${ }^{20}$ In addition, other scholars imply that the Chinese decision-makers misunderstood what the ADIZ is and what it can be used for ${ }^{21}$ since the ADIZ both failed to increase Chinese security and stability in the East China Sea and failed to give China tactical benefits in territorial disputes. ${ }^{22}$ This theory essentially posits that the CCP leadership simply did not foresee the diplomatic consequences of the ADIZ, and would help explain the implementation failures and the lack of resolve in enforcing the zone. However, the notion that China made a mistake or miscalculation does not adequately explain why did the ADIZ, as a military solution, eventually emerged as the most dominant course of action. Additionally, this explanation does not account for why the CCP refused to either correct or distance itself from its misstep upon receiving international backlash. In fact, after the announcement, both the Ministry of Defense and the Ministry of Foreign Affairs continued to publicly support the ADIZ and brush off criticisms from foreign governments and media despite this loss of face.

\footnotetext{
18 Zheng Wang, Never Forget National Humiliation: Historical Memory in Chinese Politics and Foreign Relations (New York: Columbia University Press, 2014).

19 Zheng Wang, "China's Puzzling ADIZ Decision Making:," The Diplomat, December 18, 2013, http://thediplomat.com/2013/12/chinas-puzzling-adiz-decision-making/1/2.

${ }^{20}$ Alice Miller, "The PLA in the Party Leadership Decision-making System," in PLA Influence on China's National Security Policymaking (Stanford, CA: Stanford University Press, 2015), 59-82.

${ }^{21}$ David A. Welch, "What's an ADIZ?: Why the United States, Japan, and China Get It Wrong," Foreign Affairs, December 9, 2013, https://www.foreignaffairs.com/articles/east-asia/2013-12-09/ whats-adiz.

22 Welch, "What's an ADIZ?: Why the United States, Japan, and China Get It Wrong."
} 
Explanation III: The ADIZ was Designed to Reconcile Party-Army Interests and Goals

Finally, the most compelling theory argues that the installation of the ADIZ was a part of Xi Jinping's attempts to cultivate loyalty within the PLA by aggressively addressing the security and political concerns of the Chinese military establishment. ${ }^{23}$ By 2013, events in the East China Sea pressured Party leadership to turn towards the hard power component of their coercive diplomacy. This meant that the CCP needed a loyal and advanced military in order to pursue their political goals. By bolstering and supporting the People's Liberation Army (PLA), the CCP is also reasserting the fact that the PLA likewise needs CCP leadership to legitimize its mission. The relationship between the CCP's political goals and the PLA's institutional interests as an explanation for the decisionmaking behind the 2013 ADIZ was alluded to in scholarship by $\mathrm{Nan} \mathrm{Li},{ }^{24}$ but was not thoroughly explored in great detail.

\section{The Argument}

This paper advocates for the Party-Army relations explanation, but also asserts that because of China's expanding foreign policy objectives, and because of its entrenched security dilemmas surrounding its territorial disputes, the relationship balance shifted in favor of the senior-level decisionmaking which permitted the establishment of the ADIZ. Unlike the army it would have been difficult for PLA Air Force (PLAAF) to advocate its interests without a perceived security threat against China. In other words, the looselyenforced 2013 ADIZ is a result of a combination of internal and external dynamics, namely rising tensions in the East China Sea region that inflated the PLA's influence as political actors. When PLA and Central Military Commission (CMC) elites attempted to capitalize on external pressures facing China's national security elites, the CCP submitted to the institutional

\footnotetext{
${ }^{23} \mathrm{Nan} \mathrm{Li}$, "Top Leaders of the PLA: The Different Leadership Styles of Jiang, Hu, and Xi," in PLA Influence on China's National Security Policymaking (Stanford, CA: Stanford University Press, 2015), 33-53.

${ }^{24} \mathrm{Nan} \mathrm{Li}$, "Top Leaders of the PLA: The Different Leadership Styles of Jiang, Hu, and Xi," in PLA Influence on China's National Security Policymaking (Stanford, CA: Stanford University Press, 2015), 33-53.
} 
interests of the PLA. This paper first discusses the theory and history behind the Chinese party-army relationship. Second, it defines the PLA's institutional interests and demonstrates how these interests shifted between 2012 and 2014. The third and fourth section brings forth evidence of the increasingly powerful influence the institutional interests of PLA, particularly the PLAAF, brought to bear in 2013. The fifth section elaborates on the regional political context that catalyzed the Chinese military establishment's surge in influence.

\section{Describing the Party-Army Relationship}

This essay postulates that the main force behind the establishment of the ADIZ is the People's Liberation Army (PLA). The PLA is the main military apparatus of the Chinese Communist Party's foreign policy. Scholars often describe this unique relationship between China's military and civilian leaders as a 'Party-Army' relationship, which means that senior PLA officers belong to the CCP and that the PLA is designed to serve the CCP, not the state of China. This essentially means that the PLA's fate is intrinsically tied to the Party, and that the Party's interests are prioritized over institutional ones. ${ }^{25}$ With that said, as CCP leaders become more invested with their foreign policy interests, China's defensive parameters will shift outward and the Party will find itself increasingly reliant on the military establishment to support CCP goals. As a result the defense establishment, while politically constrained, will have more leverage to lobby for their institutional interests.

Several scholars have written about the decision-making power and chain of command that results from the complex relationship between the PLA and the CCP. Isaac Kardon and Phillip Saunders state that the PLA can be described as an interest group of the CCP whose influence is defined by its complex relationship with Party leaders and their political agendas. ${ }^{26}$ The PLA's interests are primarily "institutionally-derived," largely focusing on the appointment of military personnel, the future direction of Chinese defense policy and the allocation of defense spending. ${ }^{27}$ As a result, the PLA has become more professional. The

\footnotetext{
${ }^{25}$ Isaac B. Kardon and Phillip C. Saunders, "Reconsidering the PLA as an Interest Group," in PLA Influence on China’s National Security Policymaking (Stanford, CA: Stanford University Press, 2015), 33-53.

${ }^{26}$ Kardon and Saunders, "Reconsidering the PLA as an Interest Group," 33-53.

27 Ibid., 37-38.
} 
interests between the military and Party bureaucracies have diverged as the PLA interests have become less personalized and more specialized. ${ }^{28}$ With that said, the PLA does not generally act as an autonomous institution, and while it may lobby for political concessions via the CMC, the PLA technically remains subordinate to the Party. This subordination has experienced cycles of faltering and reinforcement of loyalty towards the CCP since Mao first stated, "The Party controls the gun; the gun must never be allowed to control the Party." 29 The un-professionalization of the PLA must be emphasized because the CCP relies on the military to back party control in times of crisis, both during internal unrest and conflicts with foreign entities. The absence of a subordinate, devoted military would mean almost certain extinction for the Party.

There are, above all, two major assets that the CCP needs from the PLA. First, the CCP desires a military that is equipped with a modern arsenal and the required technical expertise to make the most efficient use out of this arsenal. It is important to understand that the PLA, as a military institution, has specialized knowledge in warfare which the CCP cannot gain anywhere else. As Kardon and Saunders state, "Secrecy about military capabilities and operations and the PLA's ability to tightly censor information helps insulate many military issues from civilian scrutiny, even by government officials with security clearances." 30 Furthermore, is possible that the PLA may choose guard its activities and expertise so jealously, in part, because such information gives them decisionmaking power. Moreover, "few Chinese academics or civilian think-tanks have the expertise or standing to write knowledgeably about military issues, and those who do are usually restricted to the very limited information limited in the public domain." ${ }^{1}$ Civilian leadership knows that it is in their national security interests to maintain robust military spending and develop long-range strike capacity. This concern was reflected when Xi Jinping stated, "We will enhance our combat readiness through full-scale combat simulation exercises, and reinforce the belief that as soldiers our mission is to fight, and as officers our mission is

\footnotetext{
${ }_{28}$ Kardon and Saunders, "Reconsidering the PLA as an Interest Group," 37-38.

${ }^{29}$ Ellis Joffe, "Party-Army Relations in China: Retrospect and Prospect," The China Quarterly, no. No. 146 (June 1996), http://www.jstor.org/stable/655470, 303-306.

${ }^{30}$ Kardon and Saunders, "Reconsidering the PLA as an Interest Group," 42.

31 Isaac B. Kardon and Phillip C. Saunders, "Reconsidering the PLA as an Interest Group," in PLA Influence on China's National Security Policymaking (Stanford, CA: Stanford University Press, 2015), 42.
} 
to lead our men to victory. We must train our troops strictly and provide rigid criteria for real combat, modernize our armed forces, and enhance their capacity to fulfill diverse military tasks." 32 Because of the military's monopoly on in-demand military expertise, it may significantly guide discussion regarding the military's role and priorities in national security decision-making.

The second criteria that the CCP expects from the PLA is total obedience to the Party. As mentioned before throughout China's modern history the PLA are more often than not the defining factor that allows the communist party to survive in times of political turmoil. Scholars point towards the 1960s Cultural Revolution and the 1989 Tiananmen Square Incident as being decisive crucibles for PLA allegiance toward the Party. ${ }^{33}$ In each case, the communist leadership was able to reassert control over the PLA, but at serious costs. ${ }^{34}$ Alice Miller states, "... it is not hard to imagine crises and stresses that provoke doubts among the leadership about the system's effectiveness or that provide opportunities for members of the oligarchy to subvert it." 35 This is why Xi Jinping has been adamant that ideological doctrine remains an integrated part of a soldier's training. He states,

We must uphold the Party's leadership of the armed forces. This is central to the nature and mission of the armed forces, the future of socialism, the enduring stability of the Party, and the lasting peace of the armed forces. In our efforts to strengthen our armed forces we must treat theoretical and political education as our first priority of our officers and soldiers, and the whole armed forces will follow without hesitation the commands of the Party Central Committee and the Central Military Commission at all times and under all conditions." 36

This is essentially the same message that Mao Zedong stated some 74 years and

32 Jinping Xi, "Build Strong National Defense and Powerful Military Forces: December 8-10, 2012," in The Governance of China (Beijing, China: Foreign Languages Press, 2014), 240-241.

33 Ellis Joffe, "Party-Army Relations in China: Retrospect and Prospect," The China Quarterly, no. No. 146 (June 1996), http://www.jstor.org/stable/655470, 305-307.

34 Andrew Scobell, China's Use of Military Force: Beyond the Great Wall and the Long March (Cambridge: Cambridge University Press, 2008).

35 Alice Miller, "The PLA in the Party Leadership Decision-making System," in PLA Influence on China's National Security Policymaking (Stanford, CA: Stanford University Press, 2015), 82. 36 Jinping Xi, "Build Up Our National Defense and Armed Forces: November 16, 2012," in The Governance of China (Beijing, China: Foreign Languages Press, 2014), 238. 
ten days earlier when he proclaimed, "Every Communist must grasp the truth, political power grows out of the barrel of a gun. Our principle is that the Party commands the gun, and the gun must never be allowed to command the Party." ${ }^{37}$ Like Mao and Deng before him, Xi Jinping understands that the very fabric of the CCP's grip on a single, cohesive China relied on a military bureaucracy that was unquestionably loyal to the Party. Xi Jinping has both "curried favor" with the military through his hardline approach to foreign policy, and has also shown resolve in disciplining the PLA, which is indicated by CMC calls for reform and anti-corruption trials targeting certain high-ranking PLA generals. ${ }^{38}$ In one November 2013 PLA meeting, a politburo official stated, “...it is imperative to ensure Party's absolute leadership over the military, ensure being able to win battles and perform missions, and ensure that the people's army will never change its color." ${ }^{39}$ In addition to military enforcement of social stability, an obedient PLA is foundational to the Party's national security agenda. Chinese strategic thought remains convinced that China's borders are vulnerable to hostile states, and that the country faces territorial incursions and loss of sovereignty without a strong military. ${ }^{40}$ The military is therefore considered essential to the CCP's credibility towards the Chinese people in having the capability to maintain control over a stable and secure China. The evolving role of the PLA will be further discussed further in the essay.

The indispensability of the PLA means that the civilian leaders of the CCP must cede greater institutional decision-making to the military leadership. This means that commanders have a level of autonomy when executing decisions. Strictly military decisions are made by the Central Military Commission, which acts as a liaison between the military and civilian leadership. Alice Miller

\footnotetext{
37 Zedong Mao, "Problems of War and Strategy," Selected Works of Mao Tse-Tung, 2004, https://www.marxists.org/reference/archive/mao/selected-works/volume-2/mswv2_12.htm. 38 Nan Li, "Top Leaders of the PLA: The Different Leadership Styles of Jiang, Hu, and Xi," in PLA Influence on China's National Security Policymaking (Stanford, CA: Stanford University Press, 2015), 128-131. See also: "CMC Leaders Participate in Thematic Meetings of Democratic Life in PLA Major Units,” People’s Daily, October 18, 2013, http://en.people. cn/90786/8429055.html.

39 "CMC Leaders Attend PLA's Party Building Meeting," China Military Online, November 11, 2013, http://en.people.cn/90786/8452256.html.

40 J. Andrew Nathan and Andrew Scobell, "How China Sees America," Foreign Affairs, September 2012, https://www.foreignaffairs.com/articles/china/2012-08-16/how-china-seesamerica? page $=$ show .
} 
has made the observation that through the CMC organizational structure, the Party and the PLA have managed to strike a balance between the need for PLA representation and the need to keep PLA decisions focused on the military and not influencing broader CCP politics. ${ }^{41}$ Yet, by 2012 the PLA began participating in a wider scope of national security and foreign policy activities. ${ }^{42}$ Research by Eric Hagt indicates that the twenty-first century rise of China has allowed the PLA to take more initiative in military diplomacy, such as the PLA's leading role in the military-to-military dialogues that deescalated a 2010-2011 Sino-Indian border dispute. ${ }^{43}$ This is reflected by the 2012-13 Defense white paper which states,

Deepening security cooperation and fulfilling international obligations, China's armed forces are the initiator and facilitator of, and participant in international security cooperation. They uphold the Five Principles of Peaceful Coexistence, conduct all-round military exchanges with other countries, and develop cooperative military relations that are non-aligned, non-confrontational and not directed against any third party. They promote the establishment of just and effective collective security mechanisms and military confidence-building mechanisms. ${ }^{44}$

What this research indicates is that the PLA has been proactive in promoting its own agenda both by working with the CCP via the CMC, as well as by communicating with foreign counterparts directly (or indirectly in the case of the ADIZ).

The mechanisms that link the CCP with the PLA and the extent PLA advocates are successful at pushing their agenda are difficult for scholars to

${ }^{41}$ Alice Miller, "The PLA in the Party Leadership Decision-making System," in PLA Influence on China's National Security Policymaking (Stanford, CA: Stanford University Press, 2015), 73, 79.

42 "Military and Security Developments Involving the People's Republic of China 2012," Annual Report to Congress: (Washington, DC: Department of Defense Office of the Secretary of Defense, May 2012), https://www.defense.gov/Portals/1/Documents/pubs/2012_CMPR_Final. pdf.

${ }_{43}$ Eric Hagt, "The Rise of PLA Diplomacy," in PLA Influence on China's National Security Policymaking (Stanford, CA: Stanford University Press, 2015), 237.

44 "Military and Security Developments Involving the People's Republic of China 2012," Annual Report to Congress: (Washington, DC: Department of Defense Office of the Secretary of Defense, May 2012), https://www.defense.gov/Portals/1/Documents/pubs/2012_CMPR_Final. pdf. 
accurately identify and measure because of the lack of transparency in the Chinese decision-making process. However, based on the research and scholarship that does exist, we can conclude that that - unlike a totally professional militarythe PLA tends to exert more sway in policymaking when the CCP needs the military's expertise and obedience. During twentieth-century crises, the PLA would occasionally have sudden bouts of disproportionate power which would then require a rebalance to the civil-military relationship. ${ }^{45}$ In contemporary times, PLA influence is more likely a result of more gradual CCP policy changes. With that said, because the CCP sees the PLA as an integral part of its expanding security interests, the CCP (and the CMC) must, at the very least, demonstrate a willingness to cater policy towards certain actors within the not-so-professional force, particularly the navy and the air force, in order to win over their obedience and loyalty.

\section{INTERESTS OF THE PLA}

The question remains; what are the interests of the People's Liberation Army? As stated before, the current equilibrium between the PLA-CCP means that the interests are generally institutional. The primary institutional objective of the PLA is to expand and enhance its capability to fulfill Chinese foreign policy objectives. These include maintaining influence in defense industries and research and development, increasing defense resources and funding, and increasing PLA control over their own defense budget. ${ }^{46}$ Moreover, the PLA wants to be recognized for its importance to the CCP foreign policy. Kardon and Saunders state,

The PLA's role in winning the Chinese civil war and its status as a partyarmy provide a continuous basis for demanding prestige and respect from CP leaders. Military leaders want respect for the importance of

\footnotetext{
${ }^{45}$ Ellis Joffe, "Party-Army Relations in China: Retrospect and Prospect," The China Quarterly, no. No. 146 (June 1996), http://www.jstor.org/stable/655470. 305-307. Andrew Scobell, China's Use of Military Force: Beyond the Great Wall and the Long March (Cambridge: Cambridge University Press, 2008).

${ }^{46}$ Isaac B. Kardon and Phillip C. Saunders, "Reconsidering the PLA as an Interest Group," in PLA Influence on China's National Security Policymaking (Stanford, CA: Stanford University Press, 2015), 47.
} 
the PLA mission and expect deference to the officers and men responsible for carrying it out. This concern is not only symbolic, but substance: the desire for respect extents into a desire for acknowledgement of the PLA's professional expertise and right to speak authoritatively on military matters, in both public and private settings. ${ }^{47}$

In other words, they want the CCP leadership to pay attention and promote the contributions of PLA missions, especially in national defense and territorial integrity. This section asserts that PLA interests shifted by 2012-2013, intensifying its resolve in enforcing Chinese maritime sovereignty. This is reflected by the change in tone between the 2010 and 2012 State Council white papers on national defense. The 2010 white paper places a higher emphasis on promoting peaceful development and insuring "social harmony and stability" than it does on asserting territory, which is mostly in reference to cross-strait relations. ${ }^{48}$ However, in the 2012 defense white paper, sovereignty and territorial integrity play a much larger role in the paper's strategy and duties for national defense. As a report from CNA suggests, the 2012 report prepares China for a slightly more pessimistic outlook on international relations that emphasizes China's maritime disputes. ${ }^{49}$ While the 2012 white paper still indicates some concern for the stability of China, especially along its borders, by centering its paper on border, coastal, and airspace security, the Chinese military apparatus announces a new prioritization of military strength and assertiveness in its stance towards territorial disputes with China's neighbors. This policy shift is also reflected by two U.S. Department of Defense reports to Congress on the growth and capabilities of the Chinese military. In 2012, the DOD assessment stated the following,

In 2011, Taiwan remained the PLA's most critical potential mission, and the PLA continued to build the capabilities and develop the doctrine necessary to deter the island from asserting its sovereignty; deter, disrupt, or deny effective third-party (including the United States) intervention in

\footnotetext{
47 Kardon and Saunders, "Reconsidering the PLA as an Interest Group," 45.

48 "China's National Defense in 2010" (The State Council Information Office of the People's Republic of China, April 2, 2011), http://eng.mod.gov.cn/Database/WhitePapers/2010.htm.

49 Daniel M. Hartnett, "China's 2012 Defense White Paper: Panel Discussion Report," CNA China Studies (Center for Naval Analysis, September 2013), https://www.cna.org/CNA_files/ PDF/CCP-2013-U-005876-Final.pdf.
} 
a potential cross-Strait conflict; and defeat Taiwan forces in the event of hostilities. ${ }^{50}$

This seems to suggest that senior Chinese policymakers were more focused on Taiwan as a threat than on territorial dispute with other neighboring states. Party leaders perhaps viewed the PLA, including the PLAAF, as serving as leverage in their cross-strait diplomacy. It is clear from the 2012 State Council Paper and the 2013 DOD assessment on Chinese military capabilities ${ }^{51}$ that the PRCTaiwanese relations remained a priority in Chinese strategic outlook. However as mentioned before, territorial disputes with Japan began to seriously come to CCP attention by early 2013 .

The 2013 DOD assessment indicates that by 2013, China's territorial disputes with Japan greatly intensified after Japan began maneuvering to legally claim the Senkaku/Diaoyu islands (despite being aware of conflicting Chinese claims). ${ }^{52}$ Because Japan's actions are, in the minds of Chinese military and civilian elites, violations of China's sovereignty and territorial integrity, the leadership must produce a strong response. Failure to adequately answer to foreign encroachments could result in a severe loss of face for both the CCP leadership and the PLA commanders, whose historical legitimacy is derived from its duty towards the preservation of the Chinese people and Chinese sovereignty. In light of the 2012-2013 controversies, the Party felt pressured to enhance the PLA's role in Chinese foreign policy issues to placate its domestic audience and reestablish itself as the legitimate, unchallengeable authority over China. It was in the context of the 2012 white paper on national defense and the expanding PLA mission in which the 2013 ADIZ was born.

\section{Growing Influence of the PLA Air Force}

Evidence indicates that the CCP wanted holistically increase the volume and the efficiency of its military force. This is reflected by the overall steady

\footnotetext{
50 "Military and Security Developments Involving the People's Republic of China 2012," Annual Report to Congress: (Washington, DC: Department of Defense Office of the Secretary of Defense, May 2012), https://www.defense.gov/Portals/1/Documents/pubs/2012_CMPR_ Final.pdf, 2-3.

51 "Military and Security Developments Involving the People's Republic of China 2013," 4.

52 "Military and Security Developments Involving the People's Republic of China 2013," 3.
} 
increases in the PLA budget, ${ }^{53}$ as well as its continuous research and development of military technology that enhances China's strike capabilities. More specifically, the PLA Army can no longer be the disproportionate focus of the PLA as it traditionally was during the Twentieth century. Chinese planners have realized that a modern military requires an effective 'blue-water' navy and an air force that balances offensive and defensive purposes. This section specifically looks at the gradual evolution of the PLAAF because of its role as primary coordinator of Chinese air defense and enforcer of air sovereignty, which would include the 2013 ADIZ.

A 2012 essay on the PLAAF influence on policy making states, "As a result of bureaucratic politics, an analysis of missions divided between air force and other services does not suggest that the PLAAF's role and influence are likely to change in the future..." ${ }^{4}$ PLA's traditional emphasis of the ground forces, as well as competition from the PLA Navy, still inhibit the PLAAF from taking a dominant voice in PLA and national security policy. However, both the State Council defense white papers as well as U.S. Department of Defense reports suggest that general modernization efforts between 2010 and 2013 have allowed the PLAAF to make strides in increasing its capabilities as well as its purview of military influence. This mandate, alongside the fact that one of the $\mathrm{CMC}$ vice chairman positions has been occupied by a succession of air force generals, demonstrate that the PLAAF is seen by Chinese policymakers as a crucial element to Chinese national security plans.

The changing tone between the 2010 and the 2012 white papers on defense not only demonstrates a general increase in attention to China's territorial disputes in Chinese national security, but also implies a greater role for the PLAAF. The 2012 paper on defense strategy stresses the importance of the PLAAF and Chinese air security stating,

The PLAAF is the mainstay of national territorial air defense, and in accordance with the instructions of the CMC, the PLAA, PLAN and PAPF

\footnotetext{
53 "Military and Security Developments Involving the People's Republic of China 2013," Annual Report to Congress: (Washington, DC: Department of Defense Office of the Secretary of Defense, 2013), 45.

${ }^{4}$ Xiaoming Zhang, "The PLAAF's Evolving Influence Within the PLA and upon National Policy," in The Chinese Air Force: Evolving Concepts, Roles, and Capabilities (Washington, DC: National Defense University Press, 2012), 86.
} 
all undertake some territorial air defense responsibilities. In peacetime, the chain of command of China's air defense runs from the PLAAF headquarters through the air commands of the military area commands to air defense units. ${ }^{55}$

Admittedly, the 2010 white paper also states that the "PLAAF is the mainstay of national territorial air defense..." 56 In both the 2010 and the 2012 paper, the role of the PLAAF is elaborated in the papers' general descriptions on the PLA's forces and respective duties. However, unlike the 2010 paper, the role of the PLAAF is further elaborated in a separate paragraph on the role air defense plays in "defending national sovereignty, security, and territorial integrity." 57 This most likely indicates that by 2013, as China's eastern theater territorial disputes intensified, the CCP's view on the role of defending airspace played a more prominent position than it did in previous years. While this mandate of responsibility (over PLAN or PLAAF) may seem to be an obvious choice, once again this must be considered in the context of a military that has glorifies the historic role of its ground forces.

The 2013 Department of Defense assessment of the PLA also indicates that the role of the PLAAF and its subsequent political influence in national security policymaking, increased after 2010. The 83-page 2013 assessment discusses a number of "special topics" that the 43-page 2010 report does not. Two of these special topics concern PLAAF matters: the development of PLAAF stealth aircraft and the development of national integrated air defense systems. According to the report, China hopes that in developing aircraft with stealth technologies it may increase its regional military power in terms of its strike capabilities and projection. ${ }^{58}$ The incorporation of stealth aircraft and antistealth aircraft capabilities could be used to for a multitude of offensive and

55 "The Diversified Employment of China's Armed Forces" (Information Office of the State Council, April 16, 2013), http://eng.mod.gov.cn/Database/WhitePapers/2012.htm.

56 "China's National Defense in 2010" (The State Council Information Office of the People's Republic of China, April 2, 2011), http://eng.mod.gov.cn/Database/WhitePapers/2010.htm. 57 Ibid.

58 "Military and Security Developments Involving the People's Republic of China 2013," Annual Report to Congress: (Washington, DC: Department of Defense Office of the Secretary of Defense, 2013). 66. 
defensive missions beyond China's borders. ${ }^{59}$ The 2010 report also discussed China's interest in stealth technology; however, the DOD's more acute interest in these advances in 2013 may indicate a growing concern for the fruition of Chinese technological aspirations. These investments in stealth fighter technology demonstrates a determined interest in correcting some of the imbalances discussed by Zheng Xiaoming's 2012 critique of PLAAP role in Chinese national security. ${ }^{60}$

The second PLAAF special topic that the reports discusses is the development of an Integrated Air Defense System designed "to defend key strategic cities and borders, territorial claims, and forces against threats from the air," particularly from precision-strike weaponry. ${ }^{61}$ According to the report, this IADS is a "multilayered system" that would employ a number of different anti-aircraft measures such as batteries and surface to air missiles. ${ }^{62}$ In addition, the IADS is developing early warning aircraft and platforms and a C4ISR network, which can target enemy aircraft and missiles and enhance communication as well as the responses between different units and weapons systems. ${ }^{63}$ The development of the IADS reflects China's growing concern for the defense of its territorial integrity and air sovereignty. Moreover, the report implies that the PLAAF is a leader in this defense system with some support from the PLA navy. ${ }^{64} \mathrm{CMC}$ investiture in projects such as the IADS and the research and development of aircraft that use an advanced level of technology demonstrates that 1.) by 2013, the PLAAF was beginning asserting its presence in Chinese national security goals; 2.) the completion of such systems might very well have further positive effects on the CCP's perception of the PLAAF as a valuable, if not absolutely necessary independent asset.

What the China State Council white papers and the U.S. DOD assessments of China's combat-readiness show is that from 2010-2013, China showed signs of

\footnotetext{
59 "Military and Security Developments Involving the People’s Republic of China 2013,” 66 ${ }^{60}$ Xiaoming Zhang, "The PLAAF's Evolving Influence Within the PLA and upon National Policy," in The Chinese Air Force: Evolving Concepts, Roles, and Capabilities (Washington, DC: National Defense University Press, 2012). 87-89.

61 "Military and Security Developments Involving the People's Republic of China 2013," Annual Report to Congress: (Washington, DC: Department of Defense Office of the Secretary of Defense, 2013), 66.

62 "Military and Security Developments Involving the People’s Republic of China 2013," 67.

63 Ibid., 68.

64 Ibid,. 66-68.
} 
attempting to increase its military capacity to assert Chinese territorial claims, both maritime and airspace. While China's military interest in modernization and high-tech warfare stems back well before the 2010s, ${ }^{65}$ new arguments with Japan over old territorial disputes, as well as the presence of a new, assertive General-Secretary, the PLA had further incentives to accelerate its institutional interests in both expanding their role and their military might. Furthermore, DOD reports show that within these evolutions, the PLAAF (which had suffered from historic neglect) now stood to gain a vital place in the PLA's renewed sense of purpose to protect the Party and the Chinese people from foreign violations of Chinese sovereignty. By 2013, the PLAAF was on the receiving end of greater attention and patronage from military and civilian elites.

\section{Party-Army Politics in the Context of a Sino-Japanese Security Dilemma}

As stated before, this paper puts special emphasis one the role of partyarmy relations in Chinese national security decisions, but changes in this relationship do not occur in a vacuum outside of external politics. Rather a security dilemma has reshaped the party-army relationship. M. Taylor Favel argues that there are three directions the PLA may lobby CCP policymakers toward regarding CCP stances on territorial disputes: the PLA may push for new territorial claims, for an expansion of regarding pre-existing Chinese territorial claims, or a more aggressive foreign policy approach advocating and enforcing territorial claims. Using Favel's premise, the ADIZ is a result of PLAAF attempts to pressure the CMC and CCP into a new means of enforcing Chinese airspace claims. ${ }^{66}$ In fact, Favel and Shinji Yamaguchi claim that PLA commanders, such as Lanzhou District Airforce Commander Zhu Qingyi, were pushing for an ADIZ years before 2013. ${ }^{67}$ However this failed to pass during the $\mathrm{Hu}$ Administration.

\footnotetext{
65 Paul H.B. Godwin, "Change and Continuity in Chinese Military Doctrine, 1949-1999," in Chinese Warfighting: The PLA Experience Since 1949, ed. Mark A. Ryan, David M. Finkelstein, and Michael A. McDevitt (New York: Routledge, 2015).

${ }_{66}$ Taylor M. Fravel, "The PLA and National Security Decision-making: Insights from China's Territorial and Maritime Disputes” (Stanford, CA: Stanford Security Studies, 2015), 250-252. ${ }^{67}$ Shinji Yamaguchi, "Briefing Memo: The Foreign Policy of Xi Jinping's Administration and The Establishment of China's Air Defense Identification Zone" (The National Institute for Defense Studies News, September 2014), http://www.nids.mod.go.jp/english/publication/eastasian/pdf/2015/east-asian_e2015_03.pdf.
} 
${ }^{68}$ What accounts for the timing of the East China Sea ADIZ? The answer is that in 2012-2013, Japan and China were engaged in a territorial dispute over the Diaoyu/Senkaku Islands. This is a maritime territorial dispute between China and Japan that flared up in 2012 and in 2013, but it has its roots in claims dating back to the early 1900's. ${ }^{69}$ Although these islands hold little intrinsic value, they do have strategic value, and more importantly, political value. When Japan decided to nationalize these islands, ${ }^{70}$ the CCP found itself scrabbling to legitimize its historic territorial assertions in the region, salvaging Party legitimacy. Because of this external stimulus the CCP automatically found itself at a new equilibrium with the PLA, in which the PLA had an improved position to leverage their institutional interests. In other words, the CCP's increased need for military power loyal to the CCP mission meant that the CCP had to become more acquiescent to PLA lobbying and offered them an opportunity to assert more decision-making clout. Requests and ideas, especially those that have been floated by military generals, were more likely to be approved.

By early 2013, the Chinese Communist Party began to believe that its neighbors, particularly Japan, were challenging an order that safeguarded Chinese territorial claims. The Sino-Japanese dispute over control of the Senkaku/Diaoyu Islands has a legacy that stretches well beyond 2012. Scholars like M. Taylor Favel argue that, "Before September 2010, China had pursued a largely passive approach to the dispute over the Senkakus. Indeed, China sought to minimize attention to the dispute." ${ }^{11}$ His research suggests that People's Daily and PLA Daily articles mentioning the dispute only increased in number after 2012. ${ }^{72}$ Moreover, he also argues that military engagement in the area was kept to a minimum during

\footnotetext{
${ }_{68}$ Yamaguchi, "Brieing Memo: The Foreign Policy of Xi Jinping's Administration and The Establishment of China's Air Defense Identification Zone."

${ }^{69}$ For more information on the Diaoyu/Senkaku Island Dispute:"How Uninhabited Islands Soured China-Japan Ties.” BBC News, November 10, 2014. http://www.bbc.com/news/worldasia-pacific-11341139.

${ }^{70}$ Michael Green et al., "Senkaku Islands Nationalization Crisis," Counter-Coercion Series: (Washington D.C.: Center for Strategic and International Studies, June 14, 2017), https://amti. csis.org/counter-co-senkaku-nationalization/.

${ }_{71}$ Taylor M. Fravel, "The PLA and National Security Decision-making: Insights from China's Territorial and Maritime Disputes" (Stanford, CA: Stanford Security Studies, 2015), 265.

72 Fravel, "The PLA and National Security Decisionmaking: Insights from China's Territorial and Maritime Disputes," 264-266.
} 
this time ${ }^{73}$ although other scholars have made cases that would dispute the latter point. ${ }^{74}$ Regardless, neither the $2008^{75}$ nor 2010 State Council white papers on defense mention China's territorial disputes with Japan at all; yet, 2012's paper published in April 2013 does. This strategic change, as well as their strong allergy to international pressure, ${ }^{76}$ indicate an escalation of China's stance towards Senkaku/Diaoyu Islands after the Japanese government 'purchased' them in September 2012.

The dispute between Japan and China had become a security dilemma ${ }^{77}$ in which both governments felt the need to take preventative measures. For Japan, perceiving pressure from the Chinese, this mean taking control of the Senkaku/ Diaoyu Islands. Even if Japan felt justified in claiming legal jurisdiction over the islands in 2012, doing so removed any strategic ambiguity that remained between Japan and China regarding the legal stance of this territory. The removal of this strategic ambiguity was a problem for the CCP leadership. The Party had long since proclaimed these islands to be Chinese territory, albeit they could either emphasize or de-emphasize this claim based on its overall strategic relations with Japan. ${ }^{78}$ Once Japan further committed itself to its claims in September 2012, China lost the option of divorcing the Senkaku Island disputes from its foreign policy towards Japan.

It is essential to comprehend that the Party cannot afford to appear to be making territorial concessions to a foreign power without a strong objection, especially to state like Japan, whose relationship with China carries enormous

\footnotetext{
73 Taylor M. Fravel, “The PLA and National Security Decision-making: Insights from China's Territorial and Maritime Disputes" (Stanford, CA: Stanford Security Studies, 2015), 265.

${ }^{74}$ Michael J. Green, "Safeguarding the Seas: How to Defend Against China's New Air Defense Zone," Foreign Affairs, December 2, 2013, https://www.foreignaffairs.com/articles/ china/2013-12-02/safeguarding-seas.

75 "China's National Defense in 2008" (Information Office of the State Council, January 20, 2009), http://www.china.org.cn/government/whitepaper/node_7060059.htm.

76 "Diaoyu Dao, an Inherent Territory of China" (State Council Information Office, September 26, 2012), http://english.gov.cn/archive/white_paper/2014/08/23/ content_281474983043212.htm

77 Thomas J. Christensen, "China, the U.S.-Japan Alliance, and the Security Dilemma in East Asia," International Security 23, no. 4 (Spring 1999), http://isites.harvard.edu/fs/docs/icb. topic199080.files/Readings_for_October_16_/Christensen.IS.99.pdf.

${ }^{78}$ J. Andrew Nathan and Andrew Scobell, China's Search For Security (New York: Columbia University Press, 2012), 123-126.
} 
historic baggage. Since China's conception in 1949, the Party's legitimacy was based on the prosperity and security of a unified Chinese society. Thus societal stability, economic growth, territorial integrity, and national sovereignty are unconditional foundations of CCP legitimacy. Any internal or external obstacles to these goals are a challenge to the CCP's authority in the eyes of both the Party and the Chinese people. Thus, after 2012, the CCP came under enormous public pressure to strongly condemn Japan and to take measures against further alleged violations of Chinese sovereignty. For the CCP, this security dilemma meant that it felt the need to refocus its military efforts on defending Chinese-claimed sea zones and airspace in order to maintain the legitimacy of the Party. The CCP knows that their overall obligation to Chinese society may only be satisfied through a PLA that is loyal, efficient, and equipped for modern warfare. On the other hand, during this time, the CCP was not necessarily ready to gear up for outright armed conflict. In such an escalation, China would risk facing the brunt edge of the U.S. military in addition to the Japanese Maritime Defense Forces. This would not have been in its interests, which often emphasized economic growth and overseas investment opportunities. ${ }^{79}$ By investing in the PLAN and PLAAF, and supporting their initiatives to build up China's coastal defenses_-initiatives such as the 2013 ADIZ - the CCP is giving these military organizations attention and recognition. At the same time, the CCP leadership needed to avoid escalating the dispute into a crisis that might have had serious consequences for China. And in this sense, the ADIZ satisfied this objective.

As this was a military policy, it was the Ministry of Defense-acting as the face of the military apparatus - that publicly announced the installation of the ADIZ and issued informative briefings that were meant to justify the government's stance. These statements explained that the ADIZ was perceived as a necessary measure to insure air space safety and security and to defend Chinese airspace sovereignty by "avoiding misunderstanding and misjudgment." ${ }^{\circ 0}$ These public MOD statements attempt to portray China's ADIZ as legal and rational international behavior. MOD spokesmen have even indicated that the ADIZ was

\footnotetext{
79 For further indication of the broader economic and political goals of the CCP and Xi (20122014) see below: Xi, Jinping. The Governance of China. Beijing, China: Foreign Languages Press, 2014.

${ }^{80}$ Yansheng Geng, "Statement by Defense Ministry Spokesman Geng Yansheng on China's Air Defense Identification Zone (ADIZ),” Embassy of the People's Republic of China in the United States of America, December 3, 2013, http://www.china-embassy.org/eng/zt/dhfksbq2/.
} 
a tactical success for China, stating, "Actually, since the announcement of the East China Sea ADIZ, a majority of civil aviation companies with their air routes traversing the area have reported flight plans to China's civil aviation department, including some airlines of Japan." 81 These statements serve not only to implicitly endorse the ADIZ, but also back the PLA's vision of a 'safe' way to exercise China's right to defend its territorial integrity. Of course, by promoting the $\mathrm{ADIZ}$, the MOD is also promoting the PLAAF that coordinates and enforces it, thus bolstering the overall prominence of the air force.

Interestingly, the Defense Ministry is not the only department that is promoting the ADIZ. The aftermath of the ADIZ inception brought forth a tirade of questions, concerns, and criticism for other states. In all of these cases, the Ministry of Foreign Affairs was delegated the task to promote the ADIZ and defend it from foreign criticism. Through a series of statements between November 25, 2013 and February 8, 2014, the MFA spokesperson responded to criticism from Japan, the United States, and Australia reasserting the Defense Ministry's comments that the ADIZ was a legal and responsible measure to insure the security of China's air space. ${ }^{82}$ In addition, on numerous occasions, the spokesperson indicated that the ADIZ was a response to direct threats to China's air security in the East China Sea, and characterized 'right-winged forces' in Japan as underminers of East Asian peace and stability. ${ }^{83}$ Indeed, these statements are public promotions of the ADIZ and the PLA's mission to uphold CCP's dedication towards national sovereignty; however, there is another aspect that is interesting about this series of MFA comments. Like many other governments, the diplomatic establishment and military establishment may find themselves competing with each other for policy-setting sway over senior-

\footnotetext{
${ }^{81}$ Geng, "Statement by Defense Ministry Spokesman Geng Yansheng on China’s Air Defense Identification Zone (ADIZ)."

${ }^{82}$ Lei Hong, "Foreign Ministry Spokesperson Hong Lei’s Remarks on the Japanese Leader's Improper Comments on the Establishment of the East China Sea Air Defense Identification Zone by China," Embassy of the People's Republic of China in the United States of America, December 15, 2013, http://www.china-embassy.org/eng/fyrth/t1109028.htm.

83 Ibid.

- Gang Qin, “Foreign Ministry Spokesperson Qin Gang's Remarks on US Comments on China's Establishment of the Air Defense Identification Zone in the East China Sea," Embassy of the People's Republic of China in the United States of America, November 25, 2013, http:// www.china-embassy.org/eng/fyrth/t1102056.htm.
} 
most CCP officials. Hagt points out that the PLA's growing influence in national security policymaking is demonstrated by the occasional divergence between the stances of the PLA and the MFA on certain policy issues. ${ }^{84}$ In a sense, the MFA's statements could also be interpreted as acknowledgment and deference to the PLA's authority and expertise in such matters. And through these statements, one might infer that the PLA has emerged as the dominant policy-setting voice in CCP national security goals.

This CCP endorsement is vital to the sacred CCP-PLA relationship. Certainly, advancing Chinese military power will produce some tangible strategic advantages for China. With that said, what was significant about the ADIZ was not that it produced measurable benefits to Chinese national security, but that it represented a change in the party-army balance of power. As both David Welch ${ }^{85}$ and Michael Green ${ }^{86}$ correctly show, the 2013 ADIZ neither gave China leverage in its territorial dispute with Japan, nor did it establish the legitimacy of Chinese claims. And for that matter, as mentioned before, China completely failed to enforce the ADIZ when countries - ignoring protocol in protest-flew their planes over the zone. The ADIZ had little effect on China's ability to fulfill security objectives. Yet, the ADIZ was not irrational. In the eyes of Chinese policymakers, the ADIZ's practical security objectives were simply of secondary importance to its political objectives. The $2013 \mathrm{ADIZ}$ was established in a larger context of military activities, in which the CCP was attempting to show the PLA, including the PLAAF, that the military institutional interests matter. And by showing the PLA respect for its mission in the service of the Party, it is at the same time reminding the PLA to remain unquestionably loyal and obedient to the CCP's national security policies and authority.

\footnotetext{
${ }_{84}$ Eric Hagt, "The Rise of PLA Diplomacy," in PLA Influence on China's National Security Policymaking (Stanford, CA: Stanford University Press, 2015), 238. David A. Welch, "What's an ADIZ?: Why the United States, Japan, and China Get It Wrong," Foreign Affairs, December 9, 2013, https://www.foreignaffairs.com/articles/east-asia/2013-12-09/whats-adiz.

85 David A. Welch, "What's an ADIZ?: Why the United States, Japan, and China Get It Wrong," Foreign Affairs, December 9, 2013, https://www.foreignaffairs.com/articles/east-asia/2013-12-09/ whats-adiz.

${ }^{86}$ Michael J. Green, "Safeguarding the Seas: How to Defend Against China's New Air Defense Zone,” Foreign Affairs, December 2, 2013, https://www.foreignaffairs.com/articles/ china/2013-12-02/safeguarding-seas.
} 


\section{Counterarguments}

Some scholars may argue that this paper ignores public opinion and the rise of nationalism in Party-Army decision-making. Certainly nationalism and public opinion do play a role in how both the CCP and the PLA perceive its constituent interests, as both derive legitimacy from serving the Chinese people. Sometimes, popular opinion further incentivizes both of these institutions towards certain policies, such as a hardline stance towards China's historic adversaries, or stronger CCP disciplinary measures against corruption in the PLA, business, or provincial leadership. However, the choice to establish the 2013 ADIZ, as opposed to a different course of action, is not likely a direct result of a major "push" by popular opinion.

Other critics of this argument might point toward Xi Jinping's assumption of power in 2012 and argue that his more adept control over the PLA (versus Hu Jintao's) is the main reason for the pivot in party-army relations, not the territorial disputes, ${ }^{87}$ and this explains the differences between the 2010 and 2012 national security strategies. This essay does not dispute Xi Jinping's role in China's pivot to a more assertive foreign policy, nor does it deny his more confident position in party-army relations. Rather, it argues that because of the evolving capabilities of the PLA and because of a rise in China's perceived challenges to its sovereignty, $\mathrm{Xi}$ Jinping had greater incentive to take a more assertive role in party-army politics. The PLAAF was a notable beneficiary because of its inevitable role in coastal defense.

\section{Conclusion}

When analysts, pundits, and journalists talk about Chinese political advances in the Pacific, they often attempt to directly look at the resulting strategic outcome. Was it effective or not? Was it positive or negative? The problem with this approach is that it assumes that the Chinese State Council, the military establishment, and the CCP were acting as a perfect, singular decision-maker. But in reality, these organs cannot function as a unitary actor. Even though the

\footnotetext{
${ }^{87} \mathrm{Nan} \mathrm{Li}$, “Top Leaders of the PLA: The Different Leadership Styles of Jiang, Hu, and Xi," in PLA Influence on China's National Security Policymaking (Stanford, CA: Stanford University Press, 2015), 136-131.
} 
Party is deferred to as the final political authority over Chinese policymaking, it is supported by powerful bureaucracies that have entrenched institutional interests. Party-Army relationship theory is important to understanding Chinese decisionmaking because it affects how Chinese defense and security policymakers define success and failure.

The 2013 ADIZ faced overwhelming international criticism and defiance from the United States, Japan, South Korea, and Australia. Yet, China has not opted for vigorous enforcement of its ADIZ. ${ }^{88}$ One might argue that this represents a coercive diplomatic and strategic defeat rather than a victory. However, to the CCP, the ADIZ's strategic and diplomatic result may not matter as much as its implications regarding the Party's relationship with internal bureaucracies. Likewise, while many reports and analyses have attempted to predict the possibility of a second ADIZ covering the South China Sea, such predictions are too difficult to make. As with the 2013 ADIZ, the decision to implement a SCS ADIZ would inevitably calculate the complex and perpetually shifting dynamics of the CCPPLA relationship. Admittedly, to those of us who are not privy to the cabals of the PLA and CCP leadership, this 'unknown' factor remains too elusive and, for all practical purposes, incalculable for prediction.

This essay makes the argument that the installation of the ADIZ in November 2013 was authorized and endorsed by the CCP in order to cater to influential PLA institutional interests. After the Japanese government took unilateral actions regarding the Senkaku/Diaoyu Islands, to senior Party members, China's territorial disputes were no longer merely a question of China's interstate relations but were now an existential matter of Chinese unity. The Party needed to show that it still maintained absolute control of Chinese sovereignty, even if it was contested by foreign powers. Because of the CCP's sensitivity to the escalation of the Sino-Japanese security dilemma surrounding their territorial disputes, the incentive to acquiesce and endorse PLA policies that would reflect PLA institutional interests substantially increased. Chinese governmental statements that announce, justify, and support the 2013 ADIZ further reflect the "conditional-compliance" relationship between the CCP and the PLA. By defending Chinese sovereignty,

\footnotetext{
${ }_{88}$ Michael D. Swaine, "Chinese Views and Commentary on the East China Sea Air Defense Identification Zone (ECS ADIZ),” China Leadership Monitor, no. 40 (February 3, 2014), http:// carnegieendowment.org/2014/02/03/chinese-views-and-commentary-on-east-china-sea-airdefense-identification-zone-pub-54399.
} 
the PLA is seen as fulfilling an important duty in the service to the CCP and the Chinese people. Moreover, these statements demonstrate a shift in policy-setting weight from the other foreign policy-related institutions to the PLA and CMC. With that said, while the CCP requires the PLA's military expertise and power, as well as its unquestionable loyalty, in order to reinforce Chinese sovereignty, CCP backing of the ADIZ also works to fetter PLA interests to the overall CCP mission towards Chinese people. 


\section{BiBLIOGRAPHY}

Allen, Kenneth W. "The Organizational Structure of the PLAAF." In The Chinese Air Force: Evolving Concepts, Roles, and Capabilities. Washington, DC: National Defense University Press, 2012.

Cheng, Dean. "China's Newest Defense White Paper Suggests Fundamental Change in Perspective." Heritage Foundation, July 6, 2015. http://www. heritage.org/defense/report/chinas-newest-defense-white-paper-suggestsfundamental-change-perspective.

"China Exclusive: Defense Ministry Spokesman Responds to Air Defense Identification Zone Questions.” Xinhua News Agency. November 11, 2013. http://news.xinhuanet.com/english/china/2013-11/23/c_132912145. htm.

"China's National Defense in 2008." Information Office of the State Council, January 20, 2009. http://www.china.org.cn/government/whitepaper/ node_7060059.htm.

"China's National Defense in 2010." The State Council Information Office of the People's Republic of China, April 2, 2011. http://eng.mod.gov.cn/ Database/WhitePapers/2010.htm.

Christensen, Thomas J. "China, the U.S.-Japan Alliance, and the Security Dilemma in East Asia.” International Security 23, no. 4 (Spring 1999). http://isites. harvard.edu/fs/docs/icb.topic199080.files/Readings_for_October_16_/ Christensen.IS.99.pdf.

"CMC Leaders Attend PLA's Party Building Meeting." China Military Online, November 11, 2013. http://en.people.cn/90786/8452256.html.

"CMC Leaders Participate in Thematic Meetings of Democratic Life in PLA Major Units." People’s Daily, October 18, 2013. http://en.people. $\mathrm{cn} / 90786 / 8429055 . \mathrm{html}$. 
Daniel M. Hartnett. “China's 2012 Defense White Paper: Panel Discussion Report." CNA China Studies. Center for Naval Analysis, September 2013. https:/www.cna.org/CNA_files/PDF/CCP-2013-U-005876Final.pdf.

"Diaoyu Dao, an Inherent Territory of China." State Council Information Office, September 26, 2012. http://eng.mod.gov.cn/Database/ WhitePapers/2008.htm.

“Foreign Ministry Spokesperson Qin Gang's Remarks on US Comments on China's Establishment of the Air Defense Identification Zone in the East China Sea," n.d.

Fravel, Taylor M. "The PLA and National Security Decisionmaking: Insights from China's Territorial and Maritime Disputes." Stanford, CA: Stanford Security Studies, 2015.

Geng, Yansheng. "Statement by Defense Ministry Spokesman Geng Yansheng on China's Air Defense Identification Zone (ADIZ)." Embassy of the People's Republic of China in the United States of America, December 3, 2013. http://www.china-embassy.org/eng/zt/dhfksbq2/.

Godwin, Paul H.B. "Change and Continuity in Chinese Military Doctrine, 1949-1999." In Chinese Warfighting: The PLA Experience Since 1949, edited by Mark A. Ryan, David M. Finkelstein, and Michael A. McDevitt. New York: Routledge, 2015.

Green, Michael J. "Safeguarding the Seas: How to Defend Against China's New Air Defense Zone.” Foreign Affairs, December 2, 2013. https://www. foreignaffairs.com/articles/china/2013-12-02/safeguarding-seas.

Green, Michael, Katherine Hicks, Zack Cooper, John Schaus, and Jake Douglas. "Senkaku Islands Nationalization Crisis." Counter-Coercion Series: Washington D.C.: Center for Strategic and International Studies, June 14, 2017. https://amti.csis.org/counter-co-senkaku-nationalization/. 
Hagt, Eric. "The Rise of PLA Diplomacy." In PLA Influence on China's National Security Policymaking. Stanford, CA: Stanford University Press, 2015.

Hong, Lei. "Foreign Ministry Spokesperson Hong Lei’s Remarks on Allegations That China Will Soon Set up an Air Defense Identification Zone (ADIZ) over the South China Sea." Embassy of the People's Republic of China in the United States of America, February 4, 2014. http://www.chinaembassy.org/eng/fyrth/t1125641.htm.

"Foreign Ministry Spokesperson Hong Lei's Remarks on the Japanese Leader's Improper Comments on the Establishment of the East China Sea Air Defense Identification Zone by China." Embassy of the People's Republic of China in the United States of America, December 15, 2013. http://www.china-embassy.org/eng/fyrth/t1109028.htm.

Hsu, Kimberly. "Air Defense Identification Zone Intended to Provide China Greater Flexibility to Enforce East China Sea Claims." U.S.-China Economic and Security Review Commission, January 14, 2014. https://www.uscc.gov/ sites/default/files/Research/China\%20ADIZ\%20Staff\%20Report.pdf.

Joffe, Ellis. "Party-Army Relations in China: Retrospect and Prospect." The China Quarterly, no. No. 146 (June 1996). http://www.jstor.org/stable/655470.

Kardon, Isaac B., and Phillip C. Saunders. "Reconsidering the PLA as an Interest Group." In PLA Influence on China's National Security Policymaking, 33-53. Stanford, CA: Stanford University Press, 2015.

Li, Nan. "Top Leaders of the PLA: The Different Leadership Styles of Jiang, Hu, and Xi." In PLA Influence on China’s National Security Policymaking, 33-53. Stanford, CA: Stanford University Press, 2015.

Mao, Zedong. "Problems of War and Strategy." Selected Works of Mao Tse-tung, 2004. https://www.marxists.org/reference/archive/mao/selected-works/ volume-2/mswv2_12.htm. 
"Military and Security Developments Involving the People's Republic of China 2012." Annual Report to Congress: Washington, DC: Department of Defense Office of the Secretary of Defense, May 2012. https://www. defense.gov/Portals/1/Documents/pubs/2012_CMPR_Final.pdf.

"Military and Security Developments Involving the People's Republic of China 2013.” Annual Report to Congress: Washington, DC: Department of Defense Office of the Secretary of Defense, 2013.

Miller, Alice. "The PLA in the Party Leadership Decisionmaking System." In PLA Influence on China's National Security Policymaking, 59-82. Stanford, CA: Stanford University Press, 2015.

Nathan, J. Andrew, and Andrew Scobell. China's Search For Security. New York: Columbia University Press, 2012.

—. "How China Sees America." Foreign Affairs, September 2012. https:// www.foreignaffairs.com/articles/china/2012-08-16/how-china-seesamerica? page $=$ show .

Pilger, Michael. "ADIZ Update: Enforcement in the East China Sea, Prospects for the South China Sea, and Implications for the United States." Staff Research Report. Washington, DC: U.S.-China Economic and Security Review Commission, March 2, 2016.

Qin, Gang. “Foreign Ministry Spokesperson Qin Gang's Remarks on Japan's Representations about China's Establishment of the Air Defense Identification Zone in the East China Sea." Embassy of the People's Republic of China in the United States of America, November 25, 2013. http://www.china-embassy.org/eng/fyrth/t1 102057.htm.

_ . "Foreign Ministry Spokesperson Qin Gang's Remarks on US Comments on China's Establishment of the Air Defense Identification Zone in the East China Sea." Embassy of the People’s Republic of China in the United 
States of America, November 25, 2013. http://www.china-embassy.org/ eng/fyrth/t1102056.htm.

Scobell, Andrew. China's Use of Military Force: Beyond the Great Wall and the Long March. Cambridge: Cambridge University Press, 2008.

"Statement by the Government of the People's Republic of China on Establishing the East China Sea Air Defense Identification Zone." Xinhua News Agency, November 23, 2013. http://news.xinhuanet.com/english/china/201311/23/c_132911635.htm.

Swaine, Michael D. "Chinese Views and Commentary on the East China Sea Air Defense Identification Zone (ECS ADIZ)." China Leadership Monitor, no. 40 (February 3, 2014). http://carnegieendowment.org/2014/02/03/ chinese-views-and-commentary-on-east-china-sea-air-defenseidentification-zone-pub-54399.

- "The PLA Role in China’s Foreign Policy and Crisis Behavior." In PLA Influence on China's National Security Policymaking, 141-61. Stanford, CA: Stanford University Press, 2015.

"The Diversified Employment of China's Armed Forces." Information Office of the State Council, April 16, 2013. http://eng.mod.gov.cn/Database/ WhitePapers/2012.htm.

Wang, Zheng. "China's Puzzling ADIZ Decision Making:" The Diplomat, December 18, 2013. http://thediplomat.com/2013/12/chinas-puzzlingadiz-decision-making/ $1 / 2$.

- Never Forget National Humiliation: Historical Memory in Chinese Politics and Foreign Relations. New York: Columbia University Press, 2014.

Welch, David A. "What's an ADIZ?: Why the United States, Japan, and China Get It Wrong.” Foreign Affairs, December 9, 2013. https://www.foreignaffairs. 
com/articles/east-asia/2013-12-09/whats-adiz.

Xi, Jinping. "Build People's Armed Forces That Follow the Party's Commands, Are Able to Wind and Exemplary in Conduct: March 11, 2013." In The Governance of China, 242-44. Beijing, China: Foreign Languages Press, 2014.

. "Build Strong National Defense and Powerful Military Forces: December 8-10, 2012.” In The Governance of China, 240-41. Beijing, China: Foreign Languages Press, 2014.

- "Build Up Our National Defense and Armed Foreces: November 16, 2012." In The Governance of China, 237-39. Beijing, China: Foreign Languages Press, 2014.

- "China's Commitment to Peaceful Development: March 28, 2014." In The Governance of China, 290-289. Beijing, China: Foreign Languages Press, 2014.

. "Diplomacy with Neighboring Countries Characterized by Friendship, Sincerity, Reciprocity and Inclusiveness." In The Governance of China, 325-29. Beijing, China: Foreign Languages Press, 2014.

- The Governance of China. Beijing, China: Foreign Languages Press, 2014.

. "Work Together for a Better Asia Pacific: October 7, 2013." In The Governance of China, 378-88. Beijing, China: Foreign Languages Press, 2014.

- "Work Together to Build a 21st-Century Maritime Silk Road: November 3, 2013.” In The Governance of China, 220-23. Beijing, China: Foreign Languages Press, 2014.

. "Work Together to Build the Silk Road Economic Belt: September 8, 
2013.” In The Governance of China, 315-19. Beijing, China: Foreign Languages Press, 2014.

Yamaguchi, Shinji. "Brieing Memo: The Foreign Policy of Xi Jinping's Administration and The Establishment of China’s Air Defense Identification Zone." The National Institute for Defense Studies News, September 2014. http://www.nids.mod.go.jp/english/publication/east-asian/pdf/2015/eastasian_e2015_03.pdf.

Yang, Yujun. "China Exclusive: Defense Ministry Spokesman Responds to Air Defense Identification Zone Questions," November 23, 2013. http:// news.xinhuanet.com/english/china/2013-11/23/c_132912145.htm.

Zhang, Hong. "Chinese Public Offers Broad Support to ADIZ." South China Morning Post, November 29, 2013. http://www.scmp.com/news/china/ article/1368206/public-offers-broad-support-adiz.

Zhang, Xiaoming. "The PLAAF's Evolving Influence Withing the PLA and upon National Policy." In The Chinese Air Force: Evolving Concepts, Roles, and Capabilities. Washington, DC: National Defense University Press, 2012. 